Indo. J. Chem. Res., 2018, 5(2), 86-95

\title{
Waktu Optimum Hidrolisis Pati Limbah Hasil Olahan Ubi Kayu (Manihot esculenta Crantz var. Lahumbu) Menjadi Gula Cair Menggunakan Enzim a-Amilase Dan Glukoamilase
}

\author{
Optimum Time Waste Processed Starch Hydrolysis of Cassava (Manihot esculenta \\ Crantz var. Lahumbu) Into Liquid Sugar Using Enzymes $\alpha$-Amylase \\ And Glucoamylase
}

\author{
Ardiansyah, Nurlansi, Rustam Musta* \\ Department of Chemistry Education Faculty of Teacher Training and Education University of Halu Oleo \\ Kampus Bumi Tridarma; Anduonohu Kendari-South East Sulawesi - Indonesia \\ *Corresponding author, e-mail: rustam@gmail.com
}

Received: Dec. 2017 Published: Jan. 2018

\begin{abstract}
This study aims to determine optimum time of action of the enzyme $\alpha$-amylase and glucoamylase needed in hydrolyze of starch from waste processed cassava (Manihot esculenta Crantz var. Lahumbu). This research was conducted through three main stages, namely the gelatinization, liquefaction and saccharification. The method was used method are liquefaction and saccharification. The variation time of the stage liquefaction: $12 ; 24 ; 36$; 48; 60; and 72 minutes and the saccharification stage are: $9 ; 18 ; 27 ; 36 ; 45 ; 54$; and 63 hours. The results showed that the optimum time required for stage liquefaction using $\alpha$-amylase enzyme is 48 minutes on the condition of a temperature of $80{ }^{\circ} \mathrm{C}$ with a value of $0.09 \%$ amylose levels were measured using UV-Vis spectrophotometer. The optimum time required for saccharification step using a glucoamylase which is 54 hours on the conditions of a temperature of $50^{\circ} \mathrm{C}$ with the amount of reducing sugar concentration of $9.186 \mathrm{~g} / \mathrm{L}$ as measured using a UVVis spectrophotometer.
\end{abstract}

Keywords: Waste cassava starch hydrolysis, $\alpha$-amylase and glucoamylase, liquid sugar.

\section{PENDAHULUAN}

Kebutuhan paling mendasar bagi sumber daya manusia suatu bangsa adalah pangan. Ketersediaan pangan dalam jumlah dan kualitas yang cukup, sangat diperlukan untuk mencapai ketahanan pangan. Namun sampai saat ini, permasalahan pangan masih menjadi problem yang sangat kompleks dalam kehidupan manusia. Penyebab dari permasalahan pangan tersebut diantaranya yaitu kurangnya ketersediaan bahan-bahan pangan, perbedaan kemampuan ekonomi masyarakat, dan juga sering gagalnya panen akibat iklim yang tidak menentu. Berbagai macam cara dilakukan oleh pemerintah dalam upaya memenuhi kebutuhan bahan pangan, seperti penggunaan bibit unggul hingga perluasan lahan produksi. Namun, jika produksi bahan pangan dalam negeri tidak mencukupi kebutuhan pangan nasional, maka impor menjadi jalan terakhir (Azis et al., 2014).

Indonesia masih bergantung pada impor untuk 5 bahan pokok, yaitu beras, jagung, kedelai, tepung terigu dan gula. Produksi gula dalam negeri masih belum mampu memenuhi kebutuhan gula nasional. Kebutuhan gula nasional tahun 2014 mencapai 5,7 juta ton yang terdiri dari 2,8 juta ton untuk konsumsi langsung masyarakat, dan 2,9 juta ton untuk memenuhi kebutuhan industri. Banyak produsen gula masih mengeluhkan biaya produksi yang mahal dan hasilnya belum mampu bersaing dengan gula impor, baik dalam kualitas maupun kuantitas (Azis et al., 2014).

Menurut Richana (2006), upaya yang dilakukan untuk mengurangi impor gula yaitu dengan cara terus meningkatkan produksi gula dalam negeri. Disamping itu, mencari alternatif bahan pemanis lain sebagai subtitusi gula. Gula alternatif yang sekarang sudah digunakan adalah gula dari pati, seperti sirup glukosa yang salah satunya dihasilkan dari tanaman ubi kayu. Sirup glukosa atau gula cair yang dihasilkan dari pati mempunyai rasa dan kemanisan yang hampir sama dengan gula sukrosa atau gula tebu. Sirup glukosa mempunyai prospek paling menjanjikan dalam mensubtitusi gula pasir, terutama untuk kebutuhan industri minuman ringan (Soft Drink). Selain itu, sirup glukosa dapat dibuat dengan 
Ardiansyah dkk. / Indo. J. Chem. Res., 2018, 5(2), 86-95

teknologi sederhana yang ada di pedesaan, sehingga masyarakat dapat menggunakan sirup glukosa sebagai pemanis pada jajanan dan minuman, dari pada menggunakan pemanis buatan lain yang tidak sehat. Jika semua industri sirup, minuman ringan, permen, biskuit, dan jeli menggunakan sirup glukosa, maka kebutuhan gula pasir tentu akan berkurang dan tidak perlu impor gula.

Salah satu tanaman yang banyak mengandung pati adalah ubi kayu. Bagi masyarakat Sulawesi Tenggara, khususnya masyarakat Muna, Buton, dan Wakatobi, ubi kayu dijadikan sebagai sumber karbohidrat pengganti beras. Selain dapat direbus, ubi kayu dapat diolah menjadi kaopi atau tepung ubi kayu segar dan nantinya dibuat menjadi salah satu makanan khas yang di sebut kasoami (Ma'suf, 2013). Jenis ubi kayu yang umum digunakan dalam pambuatan kaopi adalah varietas lokal yang dikenal dengan nama "Lahumbu". Jenis ubi kayu ini tidak dapat direbus karena rasanya yang agak pahit.

Limbah cair dari proses pembuatan kaopi ini, tidak di manfaatkan dan dibuang begitu saja. Sementara itu, limbah cair ini masih banyak mengandung sari pati. Jika dibiarkan begitu saja, limbah cair tersebut dapat menimbulkan bau yang tidak sedap dan menyengat. Jika limbah cair tersebut di tampung, maka dapat diperoleh suatu endapan pati yang nantinya dapat digunakan sebagai bahan dasar dalam pembuatan gula cair (sirup glukosa). Gula cair (sirup glukosa) dapat dibuat dengan cara hidrolisis pati menggunakan enzim $\alpha$-amilase dan glukoamilase (Chandra et al., 2013). Faktor-faktor yang dapat mempengaruhi proses hidrolisis pati secara enzimatis yaitu konsentrasi substrat, konsentrasi enzim, suhu, $\mathrm{pH}$, dan lama proses hidrolisis. Hidrolisis pati menjadi sirup glukosa dilakukan melalui 3 tahapan, yaitu gelatinisasi, likuifikasi, dan sakarifikasi (Rahmawati, 2015).

Tahap gelatinisasi merupakan tahap awal yang dilakukan dengan cara memanaskan campuran pati dan air (suspensi pati) hingga terjadi perubahan bentuk menjadi kental. Tahap selanjutnya yaitu likuifikasi merupakan proses hidrolisis pati menjadi molekul-molekul yang lebih kecil seperti maltosa, glukosa dan dekstrin dengan bantuan enzim $\alpha$-amilase. Waktu reaksi yang diperlukan untuk mengubah pati menjadi dekstrin dengan bantuan enzim $\alpha$-amilase yaitu sekitar 60-180 menit. Tahap Sakarifikasi merupakan tahap hidrolisis lanjutan dari tahap likuifikasi dengan menggunakan enzim glukoamilase. Waktu reaksi yang diperlukan untuk mengubah dekstrin menjadi glukosa dengan bantuan enzim glukoamilase yaitu sekitar 48-96 jam (Rahmawati, 2015). Waktu reaksi merupakan salah satu faktor yang mempengaruhi kerja enzim dalam proses hidrolisis pati. Semakin lama waktu reaksi, maka kerja enzim pula akan semakin optimum. Namun setelah mencapai titik optimum, maka kerja enzim akan menurun. Oleh karena itu, penentuan waktu optimum reaksi enzimatis sangat penting, karena hasilnya dapat dijadikan sebagai parameter dalam pembuatan gula cair (Murtiaz, 2015).

Menurut Amin (2006) pengolahan ubi kayu menjadi beberapa produk olahan merupakan upaya untuk mendukung program ketahanan dan diverifikasi pangan serta menjadi salah satu solusi masalah ketergantungan dan kelangkaan suatu bahan pokok. Pengolahan limbah cair ubi kayu menjadi gula cair merupakan langkah strategis dan ekonomis bagi pengembangan ubi kayu menjadi berbagai macam produk olahan. Selain itu, hal ini juga merupakan salah satu bentuk pemanfaatan ubi kayu yang lebih optimal dan sekaligus sebagai usaha mengurangi pencemaran lingkungan.

Berdasarkan latar belakang di atas telah dilakukan penelitian tentang waktu optimum hidrolisis pati limbah hasil olahan ubi kayu (Manihot esculenta Crantz var. Lahumbu) menjadi gula cair menggunakan enzim $\alpha$-amilase dan glukoamilase.

\section{METODOLOGI}

\section{Bahan}

Bahan yang digunakan adalah ubi kayu (Manihot esculenta Crantz var. Lahumbu), enzim $\alpha$-amilase, enzim glukoamilase, larutan iod $\left(\mathrm{I}_{2}\right.$ dan KI), amilosa murni, etanol 95\%, $\mathrm{NaOH} 1 \mathrm{M}$, $\mathrm{CH}_{3} \mathrm{COOH} 1 \mathrm{M}$, Pereaksi Nelson-Somogy, larutan Arsenomolibdat, larutan Luff Schrool, arang aktif, dan aquades.

\section{Alat}

Peralatan yang digunakan yaitu alat-alat gelas (tabung reaksi, gelas beaker, Erlenmeyer, labu takar, buret, gelas ukur, pipet tetes, pipet volume), penangas listrik, spektrofotometer UV- 
Vis, neraca analitik, Hot Plate, plat tetes, oven, $\mathrm{pH}$ meter, termometer, botol semprot, batang pengaduk, kertas saring, spatula, dan panci.

\section{Prosedur Kerja}

Preparasi Sampel Pati dari Ubi kayu (Manihot esculenta Crantz var. Lahumbu)

Ubi kayu (Manihot esculenta Crantz var. Lahumbu) sebanyak $15 \mathrm{Kg}$ dikupas dari kulitnya lalu dibersihkan dari kotoran dengan air bersih dan digiling agar didapat hasil yang halus dan ukuran yang merata. Selanjutnya disaring dengan menggunakan saringan modifikasi sambil di peras hingga kering. Kemudian filtrat yang diperoleh didiamkan dalam wadah beberapa saat hingga terbentuk endapan didasar wadah. Selanjutnya endapan dipisahkan dari airnya dan dijemur hingga kering dan di angin-anginkan di udara terbuka. Diperoleh 5,3 Kg tepung pati dari ubi kayu (Manihot esculenta Crantz var. Lahumbu).

\section{Pembuatan Kurva Standar Amilosa Pembuatan Larutan Induk Amilosa 4000 ppm}

Sebanyak $400 \mathrm{mg}$ amilosa murni dimasukkan ke dalam tabung reaksi. Kemudian ditambahkan $1 \mathrm{~mL}$ etanol $95 \%$ dan $1 \mathrm{~mL}$ $\mathrm{NaOH} 1 \mathrm{M}$. Campuran dipanaskan dalam air mendidih selama 10 menit. Selanjutnya dipindahkan dalam labu takar $100 \mathrm{~mL}$ dan tambahkan aquades hingga batas tera. Setelah itu, dikocok hingga homogen.

\section{Penentuan Kurva Standar Amilosa}

Dibuat larutan standar amilosa dengan variasi konsentrasi: $40 \mathrm{ppm} ; 80 \mathrm{ppm} ; 120 \mathrm{ppm}$; $160 \mathrm{ppm}$; dan $200 \mathrm{ppm}$ dengan cara dipipet larutan induk amilosa $4000 \mathrm{ppm}$ masing-masing sebanyak $1 ; 2 ; 3 ; 4$; dan $5 \mathrm{~mL}$ lalu dimasukan ke dalam 5 buah labu takar $100 \mathrm{~mL}$. Kemudian masing-masing labu takar ditambahkan $\mathrm{CH}_{3} \mathrm{COOH} 1 \mathrm{M}$ sebanyak 0,$2 ; 0,4 ; 0,6 ; 0,8$; dan $1 \mathrm{~mL}$. Disiapkan pula larutan blangko dalam labu takar $100 \mathrm{~mL}$. Larutan blangko digunakan untuk tujuan kalibrasi sebagai larutan pembanding dalam analisis fotometri. Masingmasing labu takar ditambahkan $2 \mathrm{~mL}$ larutan iod $0,1 \mathrm{~N}$. Selanjutnya ditambahkan aquades hingga batas tera dan dikocok hingga homogen. Setelah didiamkan selama \pm 20 menit, masing-masing larutan di pindahkan ke tabung reaksi dan diukur serapannya dengan spektrofotometer UV-Vis pada panjang gelombang $625 \mathrm{~nm}$. Dibuat kurva hubungan antara kadar amilosa dengan serapannya untuk diperoleh persamaan regresi yang digunakan dalam penentuan kadar amilosa dengan rumus: $y=a x+b$.

$$
\begin{aligned}
& \text { dimana }: \\
& y=\text { absorbansi sampel } \\
& a=\text { kemiringan (slope) } \\
& x=\text { konsentrasi sampel }(\mathrm{mg} / \mathrm{L}) \\
& b=\text { konstanta }
\end{aligned}
$$

\section{Pembuatan Kurva Standar Glukosa Pembuatan Larutan Induk Glukosa 500 ppm}

Sebanyak $500 \mathrm{mg}$ glukosa anhidrat dilarutkan dengan $100 \mathrm{~mL}$ aquades dalam gelas kimia $250 \mathrm{~mL}$. Kemudian dipindahkan larutan ke dalam labu takar $1 \mathrm{~L}$ dan ditambahkan aquades hingga batas tera. Selanjutnya dikocok hingga homogen.

\section{Penentuan Kurva Standar Glukosa}

Dibuat larutan glukosa dengan variasi konsentrasi $20 \mathrm{ppm}$; $40 \mathrm{ppm} ; 60 \mathrm{ppm} ; 80 \mathrm{ppm}$; dan 100 ppm dengan cara dipipet larutan induk glukosa 500 ppm masing-masing sebanyak 4; 8; 12; 16; dan $20 \mathrm{~mL}$ lalu dimasukkan kedalam labu takar $100 \mathrm{~mL}$. Selanjutnya ditambahkan aquades hingga batas tera dan dikocok hingga homogen. Disiapkan 6 buah tabung reaksi yang bersih. Kemudian masing-masing diisi dengan 1 $\mathrm{mL}$ larutan glukosa standar dan 1 tabung diisi dengan $1 \mathrm{~mL}$ aquades sebagai blanko. Selanjutnya masing-masing tabung ditambahkan $1 \mathrm{~mL}$ pereaksi Nelson-Somogy dan segera dipanaskan dalam air mendidih selama 30 menit. Diangkat dan didinginkan suhunya hingga $25^{\circ} \mathrm{C}$. Setelah dingin, masing-masing tabung ditambahkan $1 \mathrm{~mL}$ larutan arsenomolibdat, dikocok hingga semua $\mathrm{Cu}_{2} \mathrm{O}$ larut sempurna. Ditambahkan $7 \mathrm{~mL}$ aquades dan dikocok hingga homogen. Diukur serapannya pada panjang gelombang $540 \mathrm{~nm}$. Hasil pengukuran absorbansi dibuat dalam bentuk kurva standar glukosa dan ditentukan persamaan regresinya.

\section{Analisis Kadar Pati}

Dilarutkan 1 gram sampel pati dalam 150 $\mathrm{mL} \mathrm{HCl} \mathrm{3 \%} \mathrm{menggunakan} \mathrm{Erlenmeyer} 250 \mathrm{~mL}$. 
Kemudian dihidrolisis selama 30 menit dalam waterbath lalu didinginkan. Selanjutnya larutan sampel dinetralkan dengan $\mathrm{NaOH} 20 \%$ dan ditambahkan $1 \mathrm{~mL} \mathrm{CH} \mathrm{CH}_{3} \mathrm{COOH} 3 \%$. Disaring dan dipindahkan secara kuantitatif dalam labu takar $250 \mathrm{~mL}$. Ditambahkan aquades hingga batas tera dan dikocok hingga homogen. Selanjutnya dipipet $10 \mathrm{~mL}$ filtrat larutan sampel, dimasukan ke dalam gelas kimia $250 \mathrm{~mL}$, ditambahkan 25 mL larutan Luff Schrool dan $15 \mathrm{~mL}$ aquades. Dipanaskan selama 10 menit pada pendingin balik, diangkat dan didinginkan. Kemudian ditambahkan $25 \mathrm{~mL} \mathrm{H}_{2} \mathrm{SO}_{4} 25 \%, 10 \mathrm{~mL} \mathrm{KI} 20 \%$. Dititrasi dengan larutan Natrium Tiosulfat $0,1 \mathrm{~N}$ dengan menggunakan indikator larutan kanji 0,5 $\%$. Dengan cara yang sama dilakukan pula terhadap blangko dengan mengganti larutan sampel/filtrat dengan aquades. Ditentukan kadar gula yang dinyatakan sebagai glukosa dari filtrat yang diperoleh dengan rumus :

$$
\begin{aligned}
& \text { Larutan } \mathrm{Na}_{2} \mathrm{~S}_{2} \mathrm{O}_{3} \text { yang digunakan (Z) } \\
& =\frac{(\mathrm{mL} \text { blangko }-\mathrm{mL} \text { sampel })}{0,1} \times \mathrm{N}\left(\mathrm{Na}_{2} \mathrm{~S}_{2} \mathrm{O}_{3}\right) \\
& \text { dimana : } \\
& m L \text { blangko }=\text { volume } \mathrm{Na}_{2} \mathrm{~S}_{2} \mathrm{O}_{3} \text { yang digunakan }
\end{aligned}
$$

$$
\begin{aligned}
& \text { Kadar pati }(\%)=\frac{\text { bobot glukosa } \times \mathrm{Fp} \times 0,9}{\mathrm{~W}} \times 100 \% \\
& \begin{aligned}
\text { dimana }: & \\
F p & =\text { Faktor pengenceran } \\
0,9 & =\text { Faktor konversi } \\
W & =\text { berat sampel }(\mathrm{mg})
\end{aligned}
\end{aligned}
$$

\section{Analisis Kadar Amilosa dan Amilopektin}

Sebanyak $100 \mathrm{mg}$ sampel pati dimasukan ke dalam tabung reaksi. Kemudian ditambahkan 1 $\mathrm{mL}$ etanol 95\% dan $1 \mathrm{~mL} \mathrm{NaOH} 1 \mathrm{M}$. Campuran dipanaskan dalam air mendidih $\left(100{ }^{\circ} \mathrm{C}\right)$ selama 10 menit hingga terbentuk gel. Selanjutnya gel dilarutkan dengan aquades secukupnya dan dipindahkan dalam labu takar $100 \mathrm{~mL}$. Ditambahkan aquades hingga batas tera dan dikocok hingga homogen. Dipipet sebanyak 5 $\mathrm{mL}$ dari larutan sampel lalu dimasukan ke dalam labu takar $100 \mathrm{~mL}$. Ditambahkan dengan $\mathrm{CH}_{3} \mathrm{COOH} 1 \mathrm{M}$ sebanyak $1 \mathrm{~mL}$ dan $2 \mathrm{~mL}$ larutan iod $0,1 \mathrm{~N}$ (berangsur-angsur). Kemudian ditambahkan aquades hingga batas tera dan dikocok hingga homogen. Selanjutnya dipanaskan dalam penangas air pada suhu $30{ }^{\circ} \mathrm{C}$ selama \pm 20 menit, lalu di pindahkan kedalam tabung reaksi dan diukur serapannya dengan spektrofotometer UV-Vis pada panjang gelombang $625 \mathrm{~nm}$. Serapan yang diperoleh diplotkan pada kurva standar untuk memperoleh konsentrasi amilosa pada sampel (mg/L) (Yenrina, 2015). Kemudian ditentukan kadar amilosa dengan rumus :

$$
\begin{aligned}
& \text { Kadar amilosa }(\%)=\frac{C \times V \times F p}{W} \times 100 \% \\
& \text { dimana: } \\
& C=\text { konsentrasi sampel }(\mathrm{mg} / \mathrm{L}) \\
& V=\text { volume akhir sampel }(\mathrm{mL}) \\
& W=\text { berat sampel }(\mathrm{mg}) \\
& F p=\text { faktor pengenceran } \\
& \text { Kadar Amilopektin }(\%)=\text { Kadar Pati }(\%)-\text { Kadar } \\
& \text { Amilosa }(\%)
\end{aligned}
$$

\section{Waktu Optimum Hidrolisis}

Optimasi Hidrolisis Pati menggunakan Enzim o-Amilase (Likuifikasi)

Sebanyak 300 gram pati, dimasukkan ke dalam panci dan ditambahkan aquades dengan perbandingan 1: 3 (300 gram pati/900 mL aquades). Dipanaskan pada suhu $100{ }^{\circ} \mathrm{C}$ selama \pm 30 menit sambil diaduk. Pada saat terbentuk gel (tahap gelatinisasi), diatur suhunya menjadi $80{ }^{\circ} \mathrm{C}$ dan ditambahkan enzim $\alpha$-amilase ke dalam wadah sebanyak $0,15 \mathrm{~mL}$. Pada 12 menit pertama, diukur sisa kadar patinya secara:

\section{Uji kualitatif}

Uji kualitatif dilakukan dengan cara diambil $1 \mathrm{~mL}$ sampel dan ditetesi dengan larutan iod 0,1 N. Jika masih terdapat warna biru, berarti masih terdapat pati yang belum terhidrolisis oleh enzim $\alpha$-amilase.

\section{Uji kuantitatif}

Uji kuantitatif dilakukan dengan cara diambil $1 \mathrm{~mL}$ sampel di masukkan ke dalam labu takar $100 \mathrm{~mL}$ dan ditambahkan $2 \mathrm{~mL}$ larutan iod $0,1 \mathrm{~N}$. Kemudian ditambahkan aquades hingga batas tera dan dikocok hingga homogen. Selanjutnya diukur absorbansinya pada panjang gelombang $625 \mathrm{~nm}$. Hal yang sama dilakukan setiap 12 menit dan pemanasan dihentikan ketika uji iod sudah tidak memberikan warna biru. 


\section{Optimasi Hidrolisis Pati menggunakan Enzim Glukoamilase (Sakarifikasi)}

Dekstrin yang dihasilkan selanjutnya didinginkan hingga suhunya mencapai $50{ }^{\circ} \mathrm{C}$. Kemudian ditambahkan enzim glukoamilase sebanyak 0,6 mL dan diatur pada pH 5 sambil diaduk. Proses sakarifikasi membutuhkan waktu maksimal 63 jam (variasi waktu : 9 jam, 18 jam, 27 jam, 36 jam, dan 45 jam, 54 jam dan 63 jam) sambil diaduk. Pada 9 jam pertama, diukur kadar gula reduksinya menggunakan metode NelsonSomogy, dengan cara dipipet $1 \mathrm{~mL}$ larutan sampel dan diencerkan dalam labu takar $100 \mathrm{~mL}$. Selanjutnya dipipet lagi $1 \mathrm{~mL}$ larutan sampel yang telah diencerkan, ditambahkan $1 \mathrm{~mL}$ pereaksi Nelson-Somogy dan segera dipanaskan dalam air mendidih selama 30 menit. Diangkat dan didinginkan suhunya hingga $25{ }^{\circ} \mathrm{C}$. Setelah dingin, ditambahkan $1 \mathrm{~mL}$ larutan arsenomolibdat, dikocok hingga semua $\mathrm{Cu}_{2} \mathrm{O}$ larut sempurna. Ditambahkan $7 \mathrm{~mL}$ aquades kemudian dikocok hingga homogen. Diukur serapannya pada panjang gelombang $540 \mathrm{~nm}$. Dilakukan pula cara yang sama setiap 9 jam berikutnya hingga 63 jam. Waktu optimum reaksi dapat diketahui dengan dihasilkannya gula reduksi yang paling besar.

\section{HASIL DAN PEMBAHASAN}

\section{Preparasi Sampel Pati dari Ubi kayu (Manihot esculenta Crantz var. Lahumbu)}

Sampel pati dalam penelitian ini diekstrak dari umbi ubi kayu (Manihot esculenta Crantz var. Lahumbu). Preparasi sampel diawali dengan pengupasan kulit umbi dan dilanjutkan dengan pencucian menggunakan air bersih. Tujuannya untuk membersihkan kotoran (berupa tanah) yang masih menempel pada umbi. Kemudian umbi dihaluskan dengan cara diparut. Bubur ubi yang telah halus diencerkan sedikit menggunakan air dengan tujuan untuk mendapatkan pati yang lebih banyak. Disamping itu, penggunaan metode ini juga dapat menurunkan kandungan asam sianida (HCN) yang terdapat dalam sampel (Purawisastra, 2004). Menurut Baskin dalam Purwati et al. (2016), asam sianida (HCN) mudah larut dalam air karena sama-sama bersifat polar. Tahap selanjutnya diperas dengan menggunakan kain saring. Filtrat hasil perasan ditampung dan didiamkan hingga patinya mengendap. Pati yang telah mengendap dipisahkan dengan airnya dan diangin-anginkan diudara terbuka hingga kering.

Sebanyak $15 \mathrm{Kg}$ ubi kayu (Manihot esculenta Crantz var. Lahumbu) yang diekstrak sebagai sampel dalam penelitian ini, menghasilkan rendemen pati sebesar $35,33 \%$ atau beratnya sekitar $\pm 5,3 \mathrm{Kg}$. Ciri fisik dari tepung pati yang dihasilkan yaitu teksturnya halus dan berwarna putih.

\section{Analisis Kadar Pati}

Kadar pati merupakan salah satu kriteria mutu untuk tepung, baik sebagai bahan pangan maupun non-pangan. Analisis kadar pati dilakukan terhadap sampel pati yang diperoleh dari hasil ekstraksi ubi kayu (Manihot esculenta Crantz var. Lahumbu). Tujuannya untuk mengetahui kemurnian pati yang terdapat dalam sampel. Metode yang digunakan untuk penetapan kadar pati adalah metode Luff Schrool. Berdasarkan ketetapan SNI 3451: 2011, metode Luff Schrool merupakan metode yang dapat digunakan dalam analisis suatu sampel karbohidrat (BSN, 2011). Prinsip dari metode ini yaitu reduksi dari ion $\mathrm{Cu}^{2+}$ menjadi $\mathrm{Cu}^{+}$oleh gula pereduksi. Gula pereduksi adalah gula yang mempunyai kemampuan untuk mereduksi. Senyawa-senyawa yang mengoksidasi atau bersifat reduktor adalah logam-logam oksidator seperti $\mathrm{Cu}(\mathrm{II})$.

Seluruh senyawa karbohidrat yang ada dipecah menjadi gula sederhana (monosakarida) dengan bantuan katalis asam $(\mathrm{HCl} 3 \%)$ sambil dipanaskan. Hal ini bertujuan agar reaksinya dapat berjalan dengan cepat. Setelah proses hidrolisis selesai, larutan sampel dinetralkan dengan larutan $\mathrm{NaOH} 20 \%$. Larutan sampel diuji secara kualitatif dengan menggunakan kertas lakmus untuk memastikan larutan sudah mencapai netral. Pada pengujian karbohidrat dengan metode Luff Schrool, pH larutan harus diperhatikan dengan baik. Jika pH larutan terlalu rendah (terlalu asam), maka akan menyebabkan hasil titrasi akan menjadi lebih tinggi dari sebenarnya. Sebaliknya, jika pH larutan terlalu tinggi (terlalu basa), maka hasil titrasi akan menjadi lebih rendah dari sebenarnya.

Monosakarida bebas yang terbentuk akan bereaksi dengan larutan uji Luff Schrool yang mengakibatkan ion $\mathrm{Cu}^{2+}$ yang terdapat dalam reagen tereduksi menjadi $\mathrm{Cu}^{+}$yang ditandai dengan perubahan warna dari biru menjadi biru 
kehitaman. Kelebihan $\mathrm{Cu}^{2+}$ yang tidak tereduksi dikuantifikasi dengan titrasi iodometri dengan menggunakan larutan standar $\mathrm{Na}_{2} \mathrm{~S}_{2} \mathrm{O}_{3} \quad 0,1 \mathrm{~N}$. Hasil analisis menunjukan bahwa bobot glukosa (gula pereduksi) dalam sampel pati yaitu sebesar 39,06 mg. Berdasarkan data tersebut, maka kadar pati yang diperoleh dengan menggunakan metode Luff Schrool adalah sebesar 87,89\%.

Menurut Richana et al. (2016), standar baku untuk tepung ubi kayu sebagai bahan baku dalam pembuatan gula cair yaitu memiliki kadar pati sebesar $\pm 80 \%$. Sementara itu, kadar pati yang diperoleh dalam penelitian ini lebih besar dibandingkan dengan standar bakunya. Hal ini dikarenakan pada metode preparasi sampel dilakukan pencucian ulang terhadap rendemen pati, sehingga senyawa terlarut dan zat pengotor lainnya ikut larut dalam air. Selain itu, terdapat korelasi antara kadar pati dengan karakteristik fisik suatu sampel tepung pati. Kenampakan fisik dari sampel pati yang diperoleh dari penilitian ini yaitu teksturnya halus dan warnanya putih. Penelitian lain yang dilakukan oleh Richana dan Sunarti (2004), menyimpulkan bahwa tingginya kadar pati suatu tepung ubi kayu (tapioka), dapat dicirikan dengan kenampakan fisiknya yang berwarna putih.

\section{Analisis Kadar Amilosa dan Amilopektin}

Polisakarida utama yang menyusun pati adalah amilosa dan amilopektin. Perbandingan amilosa dan amilopektin pada pati ubi kayu bervariasi. Analisis kadar amilosa pada sampel dilakukan berdasarkan prinsip Iodin-Binding (pengikatan iodin), dimana amilosa akan berikatan dengan iodin dan menghasilkan kompleks yang berwarna biru. Intensitas warna biru ini kemudian diukur dengan menggunakan spektrofotometer UV-Vis. Semakin tinggi intensitas warna yang terukur, maka semakin tinggi pula kadar amilosanya (Bemiller dan Whistler, 1996).

Pengukuran kadar amilosa diawali dengan penentuan kurva standar amilosa. Tujuannya yaitu untuk menentukan suatu persamaan regresi linear yang selanjutnya digunakan dalam penentuan kadar amilosa pada sampel. Kurva standar amilosa diperoleh dengan mengukur absorbansi sederetan larutan standar amilosa dengan variasi konsentrasi 0 ppm (blangko); 40 ppm; 80 ppm; 120 ppm; 160 ppm; dan 200 ppm dengan menggunakan spektrofotometer UV-Vis pada panjang gelombang maksimum ( $\lambda$ max) yaitu $625 \mathrm{~nm}$. Kurva standar amilosa dibuat dengan memplot data konsentrasi larutan standar terhadap absorbansinya. Grafik kurva standar amilosa dapat dilihat pada Gambar 1.

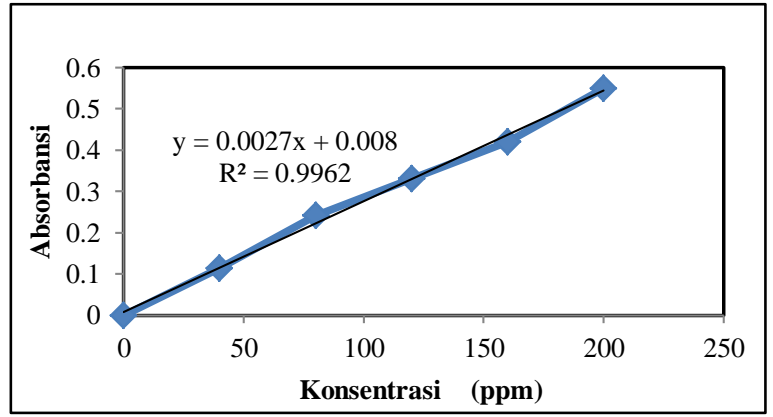

Gambar 1. Grafik kurva standar amilosa

Berdasarkan Gambar 1, grafik kurva standar amilosa, diperoleh suatu persamaan regresi $\mathrm{y}=0,002 \mathrm{x}+0,008$ dengan nilai kooefisien korelasi $(r)=0,996$. Nilai koefisien korelasi menunjukkan kekuatan hubungan antara dua variabel. Kuat dan lemahnya hubungan antara dua variabel tersebut, diukur pada skala interval $0-1$. Jika nilai kooefisien korelasi mendekati angka 1, maka kedua variabel memiliki hubungan yang sangat kuat. Hasil pengukuran kadar amilosa dan amilopektin pada sampel pati disajikan dalam Tabel 1 berikut ini.

Tabel 1 Hasil Pengukuran Kadar Amilosa dan Amilopektin

\begin{tabular}{cccc}
\hline $\begin{array}{c}\text { Sampel } \\
\text { pati } \\
(\mathbf{m g})\end{array}$ & Absorbansi & $\begin{array}{c}\text { Kadar amilosa } \\
(\%)\end{array}$ & $\begin{array}{c}\text { Kadar } \\
\text { amilopektin } \\
(\%)\end{array}$ \\
\hline 100 & 0,0244 & 16,40 & 71,49 \\
\hline
\end{tabular}

Data pada Tabel 1 menunjukan kadar amilosa dan amilopektin yang terdapat pada sampel. Kandungan amilosa pada ubi kayu umumnya lebih rendah dari pada kandungan amilopektinnya. Ubi kayu dapat dibedakan menjadi 3 golongan berdasarkan kandungan amilosanya, yaitu: (1) ubi kayu dengan kadar amilosa tinggi (> 25\%); (2) ubi kayu dengan kadar amilosa menengah (20-25\%); dan (3) ubi kayu dengan kadar amilosa rendah (< 20\%) (Winarno dalam Kusnandar, 2010). Berdasarkan Tabel 4.1, ubi kayu yang dipakai dalam penelitian ini termasuk dalam kategori ubi kayu dengan kadar amilosa rendah. Pati dengan kandungan amilosa tinggi lebih mudah larut dalam air karena banyak memiliki gugus 
hidroksil, sehingga sulit membentuk gel dan sulit mengental. Pati dengan kandungan amilosa rendah atau memiliki kandungan amilopektin tinggi memiliki sifat mengembang yang lebih baik (Kusnandar, 2010). Selain itu, pati yang memiliki kandungan amilosa tinggi bersifat kurang rekat dan kering. Sebaliknya, pati yang memiliki kandungan amilopektin tinggi memiliki sifat rekat dan basah (Hidayat et al., 2007).

\section{Optimasi Hidrolisis Pati menggunakan Enzim $\alpha$-Amilase (Likuifikasi)}

Hidrolisis pati merupakan proses pemecahan molekul amilum (pati) menjadi komponen yang lebih sederhana, seperti dekstrin, maltosa, dan glukosa (Purba, 2009). Hidrolisis pati menggunakan enzim $\alpha$-amilase diawali dengan proses pembengkakan granula pati dengan cara pamanasan atau disebut tahap gelatinisasi. Pemanasan dilakukan terhadap campuran 300 gram pati dan $900 \mathrm{~mL}$ air (perbandingan 1 : 3) sambil diaduk. Tujuan dilakukan pengadukan yaitu untuk mencegah proses gelatinisasi pati yang tidak sempurna. Gelatinisasi pati terjadi pada suhu $63{ }^{\circ} \mathrm{C}$. Pemanasan dilakukan pada suhu yang jauh lebih tinggi dari suhu gelatinisasi yaitu antara 100 $120{ }^{\circ} \mathrm{C}$. Hal ini dimaksudkan agar gelatinisasi pati dapat terjadi dengan cepat $( \pm 30$ menit). Penelitian yang dilakukan oleh Agusmanto dan Kusnandar (1995), mengatakan bahwa laju hidrolisis enzimatik jauh lebih cepat terhadap pati tergelatinisasi (gelatined starch) dari pada suspensi pati yang belum tergelatinisasi. Menurut Susilawati et al. (2008), jika likuifikasi dilakukan dibawah suhu gelatinisasi, maka pati tidak akan terurai atau terhidrolisis sempurna secara enzimatik.

Pati yang telah membentuk gel kemudian diturunkan suhunya menjadi $80 \quad{ }^{\circ} \mathrm{C}$ dan ditambahkan $0,15 \mathrm{~mL}$ enzim $\alpha$-amilase. Penggunaan suhu tersebut disesuaikan dengan jenis enzim yang digunakan. Suhu $80^{\circ} \mathrm{C}$ untuk enzim $\alpha$-amilase yang digunakan dalam penelitian ini merupakan suhu optimal yang diperoleh berdasarkan hasil optimasi enzim terhadap substrat pati yang diuji menggunakan larutan iod. Jika suhu yang diberikan di atas $80{ }^{\circ} \mathrm{C}$, maka enzim mengalami denaturasi dan tidak dapat bekerja untuk menghidrolisis pati. Sebaliknya, jika suhu yang diberikan dibawah 80
${ }^{\circ} \mathrm{C}$, maka kerja enzim sangat lambat dan membutuhkan waktu yang cukup lama dalam menghidrolisis pati. Pati akan mulai terhidrolisis oleh enzim yang ditandai dengan perubahan dari bentuk gel menjadi cair (encer) atau disebut tahap likuifikasi. Enzim $\alpha$-amilase akan menghidrolisis ikatan $\alpha$-(1,4)-glikosida dari bagian dalam secara acak baik pada amilosa maupun amilopektin (Rahmawati, 2015). Menurut Ratna dan Yulistiani (2015), pada proses likuifikasi, pati akan dipecah menjadi dekstrin, maltosa, dan glukosa. Dektrin merupakan hasil hidrolisis pati yang tidak sempurna. pengurangan panjang rantai tersebut akan menyebabkan perubahan sifat dimana pati yang tidak mudah larut dalam air, diubah menjadi dekstrin yang larut dalam air.

Senyawa amilosa yang terkandung dalam pati akan lebih cepat terhidrolisis oleh enzim $\alpha$ amilase dari pada amilopektin karena merupakan polimer dari glukosa yang hanya tersusun dari ikatan $\alpha$-(1,4)-glikosida. Menurut Purba (2009), enzim $\alpha$-amilase akan memotong ikatan $\alpha$ - $(1,4)$ glikosida pada amilosa dengan cepat pada pati kental yang telah mengalami gelatinisasi. Hasil penurunan kadar amilosa pada sampel terhadap variasi satuan waktu disajikan pada Gambar 2.

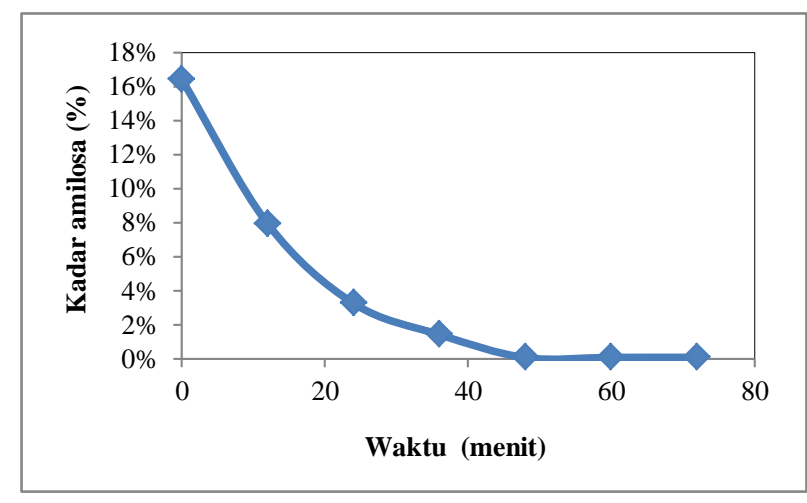

Gambar 2. Grafik penurunan kadar amilosa

Berdasarkan Gambar 2, dapat dilihat bahwa grafik penurunan kadar amilosa sebagai akibat dari hidrolisis pati oleh enzim $\alpha$-amilase terjadi secara signifikan. Pada saat 12 menit pertama setelah penambahan $0,15 \mathrm{~mL}$ enzim $\alpha$-amilase, kadar amilosa mengalami penurunan yang cukup besar jika dibandingkan dengan 12 menit berikutnya. Hal ini dikarenakan aktivitas enzim $\alpha$-amilase bekerja secara cepat. Menurut Rahmawati (2015), aktifitas enzim $\alpha$-amilase mengalami peningkatan pada substrat yang berbentuk gel. Rentang antara $0-12$ menit 
Ardiansyah dkk. / Indo. J. Chem. Res., 2018, 5(2), 86-95

merupakan fase peralihan dari bentuk gel berubah menjadi cair (likuifikasi). Setelah 12 menit berikutnya, aktivitas enzim mulai menurun sering dengan perubahan waktu. Menurunnya aktivitas enzim diakibatkan karena jumlah substrat yang mulai berkurang. Selain itu, penurunan kadar amilosa dapat dilihat melaui uji iodium (kualitatif). Amilosa dapat bereaksi dengan iodium membentuk kompleks yang berwarna biru. Intensitas warna biru mengalami penurunan seiring bertambahnya waktu jika diuji dengan larutan iod.

Waktu reaksi merupakan salah satu faktor yang mempengaruhi kerja enzim dalam proses hidrolisis pati. Semakin lama waktu reaksi, maka kerja enzim pula akan semakin optimum (Murtiaz, 2015). Waktu optimum hidrolisis pati menggunakan enzim $\alpha$-amilase terjadi pada kondisi waktu 48 menit. Hidrolisis pati menggunakan enzim $\alpha$-amilase terjadi sangat cepat. Hal ini terjadi karena jumlah amilosa yang terdapat pada sampel sangat rendah, sehingga tidak membutuhkan waktu yang lama. Berdasarkan grafik di atas, pada kondisi waktu 48 menit, kadar amilosa sangat rendah yaitu $0,09 \%$. Setelah 12 menit berikutnya, kadar amilosa sudah tidak lagi mengalami perubahan yang signifikan. Semakin rendah kadar amilosa, maka semakin rendah pula kadar patinya, karena produk hidrolisis yang dihasilkan sudah banyak..

\section{Optimasi Hidrolisis Pati menggunakan Enzim Glukoamilase (Sakarifikasi)}

Penentuan waktu optimasi hidrolisis pati oleh enzim glukoamilase dilakukan dengan menggunakan metode Nelson-Somogy. Metode ini merupakan metode penetapan kadar gula pereduksi. Pengukuran kadar gula pereduksi diawali dengan penentuan kurva standar glukosa. Kurva standar glukosa diperoleh dengan mengukur absorbansi sederetan larutan standar glukosa dengan variasi konsentrasi $0 \mathrm{ppm}$ (blangko); $20 \mathrm{ppm} ; 40 \mathrm{ppm}$; $60 \mathrm{ppm} ; 80 \mathrm{ppm}$; dan 100 ppm dengan menggunakan spektrofotometer UV-Vis pada panjang gelombang maksimum ( $\lambda \max$ ) yaitu $540 \mathrm{~nm}$. Kurva standar glukosa dibuat dengan memplot data konsentrasi larutan standar terhadap absorbansinya. Grafik kurva standar glukosa dapat dilihat pada Gambar 3.

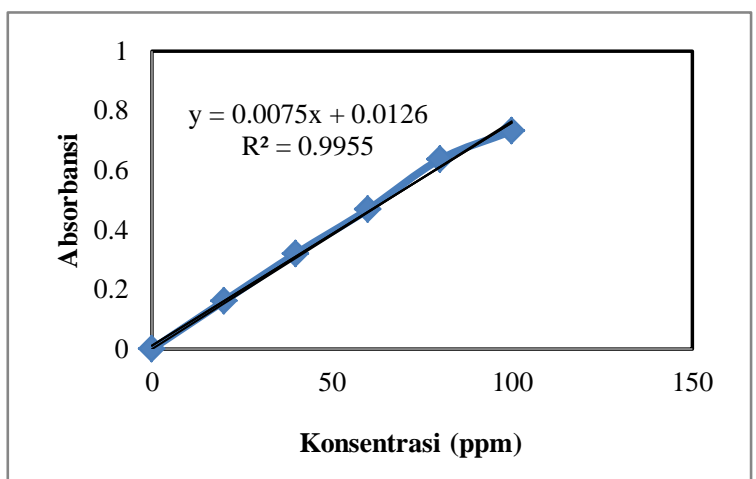

Gambar 3. Grafik kurva standar glukosa

Berdasarkan Gambar 3, diperoleh persamaan regresi untuk kurva standar glukosa y $=0,007 \mathrm{x}+0,012$ dengan nilai kooefisien korelasi $(r)=0,995$. Nilai kooefisien korelasi pada kurva standar glukosa ini tidak jauh berbeda dengan nilai kooefisisen korelasi pada penentuan kurva standar amilosa sebelumnya.

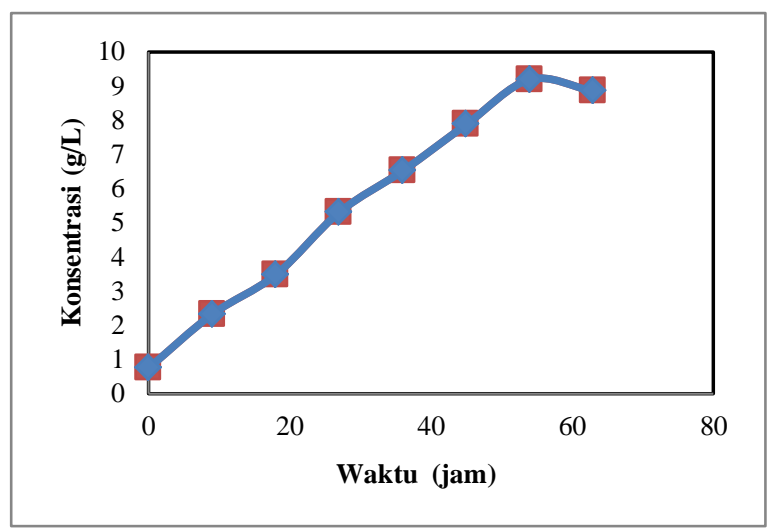

Gambar 4. Grafik peningkatan konsentrasi gula pereduksi

Selama proses hidrolisis berlangsung, enzim glukoamilase akan memecah dekstrin menjadi glukosa. Semakin lama proses hidrolisis maka gula pereduksi dalam larutan terus mengalami peningkatan. Setiap 9 jam, konsentrasi gula pereduksi dalam larutan sampel dianalisis dengan mengambil $1 \mathrm{~mL}$ larutan sampel kemudian diencerkan dalam labu takar $100 \mathrm{~mL}$. Metode yang digunakan untuk analisis konsentrasi gula pereduksi adalah metode Nelson-Somogy. Menurut jurnal hasil penelitian yang dilakukan oleh Kiyan et al. (2016), metode Nelson-Somogy lebih spesifik jika digunakan dalam penetapan gula pereduksi pada sampel. Hasil pengukuran gula pereduksi pada larutan sampel dapat dilihat pada Gambar 4. 
Ardiansyah dkk. / Indo. J. Chem. Res., 2018, 5(2), 86-95

Pada Gambar 4, terlihat bahwa semakin lama waktu reaksi maka semakin tinggi konsentrasi gula pereduksinya. Tingginya produk (gula pereduksi) yang dihasilkan dapat menghambat kerja enzim. Pada titik 54 jam, terjadi sedikit penurunan konsentrasi gula pereduksi. Hal ini terjadi akibat adanya reaksi antara enzim dan produk yang terbentuk. Tingginya konsentrasi gula pereduksi dalam larutan menandakan bahwa substrat yang semakin berkurang, sehingga sebagian gula pereduksi membentuk kompleks kembali dengan enzim atau dikenal dengan istilah penghambatan unkompetitif. Menurut Suhartono (2001), penghambatan unkompetitif merupakan salah satu penghambatan dari reaksi enzimatis yang terjadi akibat dari akumulasi produk oleh reaksi enzim itu sendiri dan terjadi secara reversible (dapat balik).

Menurut Melliawati dalam Bandjar et al. (2015), enzim glukoamilase dapat menghidrolisis ikatan $\alpha-(1,4)$ glikosidik pada amilosa maupun amilopektin. Enzim ini juga dapat memutus ikatan $\alpha$ - $(1,6)$ glikosidik pada titik percabangan yang terdapat pada amilopektin dengan laju yang lebih rendah. Hasil analisis awal sampel menunjukkan bahwa, kadar amilopektin lebih tinggi dibandingkan dengan kadar amilosa, sehingga jumlah titik percabangan $\alpha-(1,6)$ glikosidik sangat banyak. Oleh karena itu, hidrolisis pati menggunakan enzim glukoamilase membutuhkan waktu yang lebih lama dibandingkan dengan enzim $\alpha$-amilase. Waktu optimum hidrolisis pati dengan menggunakan enzim glukoamilase yaitu 54 jam dengan konsentrasi gula pereduksi sebesar 9,186 g/L.

\section{KESIMPULAN}

Kesimpulan dari penelitian ini yaitu waktu optimum kerja enzim $\alpha$-amilase yang dibutuhkan dalam menghidrolisis pati dari limbah hasil olahan ubi kayu (Manihot esculenta crantz var. lahumbu) menjadi gula cair yaitu 48 menit pada tahap likuifikasi dengan nilai kadar amilosa terendah $0,09 \%$ sedangkan untuk enzim glukoamilase yaitu 54 jam pada tahap sakarifikasi dengan diperoleh jumlah konsentrasi gula pereduksi tertinggi sebesar 9,186 g/L.

\section{DAFTAR PUSTAKA}

Agusmanto, Kusnandar, 1995, Amilosa Pati Segar, BPPT Sulusuban Lampung Tengah. Buletin Teknologi dan Industri Pangan 6 (2) : 72-91.

Amin, H., 2006, Peningkatan Mutu Dan Masa Simpan Kasoami Makanan Khas Tradisional Sulawesi Tenggara Dari Bahan Baku Ubi Kayu, IPB, Bogor.

Azis, A., Suryadi, Nurnayah L., Paramita K. L., Nurhayati N, 2014, GUCAKUSI : Gula Cair dari Kulit Singkong Sebagai Alternatif Sumber Glukosa. Laporan Akhir Program Kreativitas Mahasiswa. IPB, Bogor.

Bandjar, A., Tanasale, M., \& Luhukay, M., 2015. Kinetic Parameters Determination Of Glucoamylase On Hydrolysis Reaction Of Sagoo Starch (Metroxylon sp). Indonesian Journal Of Chemical Research, 2(2), 176181.

Bemiller, J. N., Whistler, R. L., 1996, Carbohydrates. Dalam: Fennema, O. R. ed., Food Chemistry. Marcel Dekker, Inc., New York, 157-223.

Bungati, Dian D., Abidin Z., 2012, Peningkatan Nilai Tambah Ubi Kayu Menjadi Kasoami Sebagai Makanan Pokok Di Kelurahan Laompo Kecamatan Batauga Kota BauBau. Prosiding Seminar Nasional Meningkatkan Daya Saing dan Nilai Tambah Produk Pertanian Berbasis Sumber Daya Lokal. Kerjasama Universitas Padjajaran Bandung, Badan Riset Daerah Provinsi Jawa Barat, dengan BPTP Jawa Barat, Bandung.

Chandra, A., Inggrid H. M., Verawati, 2013, Pengaruh pH dan Jenis Pelarut pada Perolehan dan Karakterisasi Pati dari Biji Alpukat. Universitas Katolik Parahyangan.

Dian D., Ratule M. T., Bungati, Lutiana W. O., 2012, Kasoami Sebagai Pangan Lokal Masyarakat Buton dalam Mendukung Kemandirian Pangan Nasional. Prosiding seminar Nasional Kemandirian Pangan 2012. UNPAD-BPTP Jawa Barat-DPRD Provinsi Jawa Barat.

Hidayat, B., Ahza, A. B., Sugiyono, 2007, Karakterisasi Tepung Ubi Jalar (Ipomea batatas $L$ ) varietas Shiroyukata serta Kajian Potensi Penggunaannya Sebagai Sumber 
Ardiansyah dkk. / Indo. J. Chem. Res., 2018, 5(2), 86-95

Pangan Karbohidrat Alternatif. Jurnal Teknologi dan Industri Pangan, Bogor.

Kiyan, H., Alkayyis, Susanti, H., 2016, Perbandingan metode Somogy-Nelson dan Anthrone-Sulfat pada Penetapan Kadar Gula Pereduksi dalam Umbi Cilembu (Ipomea batatas L.). Jurnal Farmasi Sains dan Komunitas. Universitas Ahmad Dahlan, Yogyakarta.

Kusnandar, F., 2010, Kimia Pangan :Komponen Makro. Dian Rakyat, jakarta.

Ma'suf, A., 2013, Teknologi Pengolahan Ubi Kayu Menjadi Makanan Lokal Buton "Kasoami". Balai Pengkajian Teknologi Pertanian, Sulawesi Tenggara.

Murtiaz, K. D., 2015, Optimasi Produksi Gula Cair Dari Pati Sagu (Metroxylon spp.) Asal Sulawesi Tenggara. Balai Besar Penelitian dan Pengembangan Pasca Panen Pertanian, Bogor.

Purawisastra S., Yuniati H., 2004, Penurunan Kadar Sianida Singkong Pahit pada Proses Fermentasi Cair Bakteri Brevibacterium lactofermentemum BL-1M76. Balai Penelitian Bioteknologi, Bogor.

Purba, E., 2009, Hidrolisis Pati Ubi Kayu (Manihot usclenta) Dan Pati Ubi Jalar (Impomonea Batatas) Menjadi Glukosa Secara Cold Process Dengan Acid Fungal Amilase Dan Glukoamilase. Universitas Lampung, Bandar Lampung.

Purwati, Y., Thuraidah, A., Rakhmina, D., 2016, Kadar Sianida Singkong Rebus dan Singkong Goreng. Jurnal Analisis Kesehatan. Medical Laboratory Technology Journal (MLTJ), Banjarmasin.
Rahmawati, A., 2010, Pemanfaatan Limbah Kulit Ubi Kayu (Manihot utilissima Pohl) dan Kulit Buah Nanas (Ananas comosus L.) pada Produksi Bioetanol Menggunakan Aspergillus niger. UNS, Surakarta.

Rahmawati, A. Y., Aji S., 2015, Hidrolisis Tepung Ubi Jalar Ungu (Ipomea batatas L.) secara Enzimatis menjadi Sirup Glukosa Fungsional. Jurnal Pangan dan Agroindustri. 3(3)1152-1195.

Richana, N., 2006, Gula Singkong dapat Diproduksi di Pedesaan.Vol. 28, No. 3. Warta Penelitian dan Pengembangan Pertanian, Bogor

Richana, N., Budiyanto, A., Arief, R. W., 2016, Teknologi Produksi Sirup Glukosa. Balai Penelitian dan Pengembangan Pertanian, Bogor

Susilawati, Nurjana, S., Putri, S., 2008, Karakteristik Sifat Fisik dan Kimia Ubi Kayu (Manihot esculenta) Berdasarkan Lokasi Penanaman dan Umur Panen Berbeda. Jurnal Teknologi Industri dan Hasil Pertanian. Fakultas Pertanian, Lampung.

Yenrina, R., 2015, Metode Analisis Bahan Pangan Dan Komponen Bioaktif, Andalas University Press, Padang. 